\title{
Keragaman Genetik Karakteristik Buah antar 17 Genotipe Melon (Cucucmis melo L.)
}

\author{
Genetic Diversity of Fruit Traits among 17 Melon Genotypes (ucumis $\underline{\text { melo }}$ L.) \\ Amalia Nurul Huda ${ }^{1}$, Willy Bayuardi Suwarno ${ }^{2,3 *}$, dan Awang Maharijaya ${ }^{2,3}$
}

Diterima 15 Agustus 2016/Disetujui 08 Februari 2017

\begin{abstract}
Breeding of melon requires the availability of genetic diversity and extensive evaluations of the genetic materials. Evaluations on fruit quality and yield potential are among the important steps in melon breeding. This research was aimed at studying the genetic diversity of 17 melon genotypes based on fruit traits and identifying the potential genotypes to be used as genetic materials in melon breeding programs. The research was conducted from August to October 2015 at the IPB Experimental Station Tajur II, South Bogor, $250 \mathrm{~m}$ above sea level. The experiment was arranged in a single factor of randomized complete block design with four replicates. Results of the research showed that genotype effects were significant for all observed traits except for days to hermaphrodite flowering. Traits having broad sense heritability estimates greater than $50 \%$ were days to male flowering, days to harvest, fruit length, fruit diameter, flesh thickness, fruit rind thickness, fruit weight, and sugar contant. P21 and P19 genotypes were potential for fruit weight and sugar content, while P2 was potential for fruit weight and P12 for sugar content only. Fruit weight showed significant positive correlations with fruit length, fruit diameter, flesh thickness, and fruit rind thickness. Clustering based on morphological traits generally separated reticulatus and inodorus genotypes into different groups.
\end{abstract}

Key words: correlation, heritability, simultaneous selection

\section{ABSTRAK}

Pemuliaan tanaman melon memerlukan ketersediaan keragaman genetik dan evaluasi yang ekstesif pada materi genetik yang digunakan. Evaluasi karakteristik, kualitas buah, dan potensi hasil merupakan tahapan penting dalam pemuliaan tanaman melon. Penelitian ini bertujuan untuk mempelajari keragaman genetik dari 17 genotipe melon berdasarkan karakteristik kualitas buah dan mengidentifikasi genotipe potensial untuk dijadikan materi genetik dalam program pemuliaan. Percobaan dilakukan pada bulan Agustus hingga Oktober 2015 di Kebun Percobaan IPB Tajur II, Bogor Selatan (250 mdpl) menggunakan 17 genotipe melon. Penelitian dilakukan dengan menggunakan rancangan kelompok lengkap teracak (RKLT) faktor tunggal dengan empat ulangan. Hasil penelitian menunjukkan bahwa genotipe berpengaruh nyata terhadap semua karakter yang diamati kecuali umur berbunga hermaprodit. Karakter yang memiliki nilai heritabilitas arti luas lebih besar dari $50 \%$ adalah umur berbunga jantan, umur panen, panjang buah, diameter buah, tebal daging, tebal kulit, bobot, dan kadar gula. Genotipe yang memiliki potensi untuk sifat bobot buah dan kadar gula tinggi adalah P21 dan P19, sedangkan P2 dan P12 masing-masing memiliki potensi yang baik untuk bobot buah dan kadar gula saja. Karakter bobot buah memiliki korelasi positif dan nyata dengan panjang buah, diameter buah, tebal daging buah, dan tebal kulit buah. Pengelompokan berdasarkan karakter morfologi secara umum dapat memisahkan genotipe-genotipe melon reticulatus dan inodorus ke dalam grup yang berbeda.

Kata kunci: korelasi, heritabilitas, seleksi simultan

${ }^{1}$ Program Studi Pemuliaan dan Bioteknologi Tanaman, Sekolah Pascasarjana, Institut Pertanian Bogor

${ }^{2}$ Departemen Agronomi dan Hortikultura, Fakultas Pertanian, Institut Pertanian Bogor (Bogor Agricultural University), Jalan Meranti, Kampus IPB Darmaga, Bogor 16680, Indonesia Telp. \& Faks. (0251) 8629353,

${ }^{3}$ Pusat Kajian Hortikultura Tropika, LPMM Institut Pertanian Bogor, Kampus IPB Baranangsiang, Jalan Raya Pajajaran Bogor 16141, Telp. \& Faks. (0251) 8326881, 8382201

Email: willy@ipb.ac.id(*penulis korespondensi) 


\section{PENDAHULUAN}

Melon (Cucumis melo L.) merupakan salah satu komoditas hortikultura yang memiliki nilai ekonomi tinggi. Komoditas ini memiliki prospek yang menjanjikan, baik dalam nilai jual benih maupun buahnya. Kandungan vitamin pada buah melon memiliki manfaat penting bagi kesehatan tubuh. Berdasarkan data USDA (2007), melon jenis cantaloupe merupakan salah satu sumber vitamin $\mathrm{C}$, vitamin $\mathrm{A}$, kalium, vitamin B6, asam folat, dan niasin.

Berdasarkan data BPS (2016) produksi melon di Indonesia menunjukkan adanya peningkatan sejak tahun 2010 (85 161 ton) hingga 2014 (137 887 ton). Pada tahun 2015 produktivitas melon mencapai 18.37 ton $\mathrm{ha}^{-1}$ dengan luas panen sebesar 8185 ha. Permintaan dan produksi melon yang tinggi perlu diimbangi dengan ketersediaan benih melon. Salah satu kendala yang dihadapi dalam budidaya melon adalah ketidaktersediaan benih pada waktu dibutuhkan. Penggunaan benih varietas melon luar negeri masih cukup besar sehingga kontinuitas ketersediaan benih tidak terjamin, demikian pula halnya dengan ketersediaan buah yang berkualitas.

Melon merupakan spesies yang memiliki keragaman genetik tinggi. Afrika merupakan daerah asal tanaman melon, sedangkan domestikasi melon dimulai di Iran. Tanaman melon kemudian menyebar ke daerah Timur Tengah dan Asia, kemudian menjadi komoditas hortikultura penting di India, Mesir, Iran, dan China. (Robinson dan Decker-Walters, 1999). Tiga kelompok melon yang populer yaitu reticulatus, inodorus, dan cantalupensis. Melon tipe inodorus umumnya bersifat nonklimakterik, sedangkan tipe reticulatus dan cantalupensis bersifat klimakterik. Pada saat buah siap panen, tangkai akan terlepas dari buahnya untuk melon tipe reticulatus, sedangkan melon tipe inodorus tangkainya tidak terlepas dari buah. Umumnya tipe inodorus memiliki tekstur daging buah renyah, sedangkan tipe reticulatus dan cantalupensis memiliki tekstur daging buah kenyal. Keragaman ini terdapat pada karakter tipe kulit buah (berjala atau tidak berjala), warna kulit buah dan warna daging buah (hijau, oranye, atau putih), tingkat kemanisan, tekstur daging buah (lembut, kenyal, atau renyah), dan daya simpan buah (Nuñez-Palenius et al., 2008; Sobir dan Siregar, 2014). Melalui kegiatan pemuliaan tanaman, diharapkan dapat dihasilkan varietasvarietas melon baru yang lebih bervariasi dan menarik minat konsumen. Serangkaian kegiatan pemuliaan melon yang berkesinambungan dan mengarah pada perakitan varietas hibrida dan bersari bebas perlu dilakukan untuk meningkatkan persaingan pasar benih di Indonesia. Varietasvarietas melon baru yang beredar di pasaran diharapkan lebih bervariasi dan adaptif dengan kondisi agroklimat sentra produksi melon.

Serangkaian kegiatan pemuliaan tanaman melon dilakukan oleh Pusat Kajian Hortikultura Tropika (PKHT) IPB yang mengarah pada perakitan varietas hibrida dan bersari bebas. Evaluasi karakteristik morfologi tanaman, karakter buah, dan potensi hasil merupakan tahap penting dalam pemuliaan tanaman melon. Penelitian ini bertujuan untuk mempelajari keragaman genetik 17 genotipe melon berdasarkan karakteristik buah dan mengidentifikasi genotipe potensial untuk karakter kadar gula dan bobot buah, yang kemudian dapat dijadikan materi genetik dalam program pemuliaan.

\section{BAHAN DAN METODE}

Penelitian dilakukan pada bulan Agustus sampai Oktober 2015 di Kebun Percobaan IPB Tajur II, Bogor Selatan 250 meter di atas permukaan laut (m dpl). Bahan tanaman yang digunakan dalam penelitian ini ialah 17 genotipe yang merupakan koleksi Pusat Kajian Hortikultura Tropika IPB, yaitu P2, P3, P5, P7, P9, P10, P12, P18, P19, P21, $\mathrm{P} 23, \mathrm{P} 25, \mathrm{P} 26, \mathrm{P} 27, \mathrm{P} 29, \mathrm{P} 31$, dan $\mathrm{P} 34$ Penelitian dilakukan dalam rancangan kelompok lengkap teracak (RKLT) faktor tunggal dengan empat ulangan. Pengamatan mengacu pada Descriptor for Melon (Cucumis melo L.) dari IPGRI (International Plant Genetic Resources Institute) tahun 2003.

Persiapan lahan dilakukan melalui tahap pengolahan tanah dan pembuatan bedengan. Pupuk dasar yang diberikan yaitu pupuk kandang dengan dosis 20 ton ha ${ }^{-1}$, urea dosis $200 \mathrm{~kg} \mathrm{ha}^{-1}, \mathrm{SP}-36$ dosis $200 \mathrm{~kg} \mathrm{ha}^{-1}$ dan KCl dosis $200 \mathrm{~kg} \mathrm{ha}^{-1}$. Jarak tanam yang digunakan adalah $60 \mathrm{~cm} \times 60 \mathrm{~cm}$. Pemangkasan cabang 
lateral dilakukan kecuali pada cabang ke-9 sampai ke-12. Pupuk susulan berupa pupuk NPK diaplikasikan dalam bentuk larutan (konsentrasi $20 \mathrm{~g} \mathrm{~L}^{-1}$ air) dan diberikan pada pangkal batang tanaman setelah berumur 7, 14, $21,28,35,42$, dan 49 hari setelah tanam (HST), serta pupuk $\mathrm{KNO}_{3}$ pada $45 \mathrm{HST}$.

Karakter yang diamati meliputi karakter kuantitatif dan kualitatif. Karakter kuantitatif meliputi umur berbunga jantan, umur berbunga hermaprodit, umur panen, panjang buah, diameter buah, tebal daging, tebal kulit, bobot buah, dan kadar gula. Umur berbunga jantan dihitung mulai dari waktu pindah tanam hingga waktu munculnya bunga jantan pertama, demikian halnya dengan untuk umur berbunga hermaprodit. Umur panen dihitung mulai dari waktu pindah tanam hingga buah tersebut siap untuk dipanen. Karakter kualitatif yang diamati meliputi ada tidaknya juring, intensitas jala, distribusi jala, bentuk buah, warna permukaan buah, warna daging buah, dan tekstur daging buah.

Analisis ragam dan uji perbedaan nilai tengah menggunakan metode uji jarak berganda Duncan (DMRT) pada taraf nyata 5\% dilakukan dengan menggunakan perangkat lunak SAS dan Microsoft Excel. Nilai heritabilitas arti luas dihitung dari perbandingan antara ragam genotipik dan ragam fenotipik berdasarkan nilai harapan kuadrat tengah. Analisis korelasi Pearson dilakukan untuk melihat ukuran keeratan hubungan antar karakter yang diamati dalam percobaan, menggunakan perangkat lunak STAR 2.0.1 (bbi.irri.org). Analisis gerombol (cluster analysis) dilakukan untuk memperoleh informasi pengelompokan genotipe berdasarkan karakter kualitatif dan kuantitatif. Perhitungan koefisien ketidakmiripan antar genotipe menggunakan metode Gower dan pengelompokan (clustering) menggunakan metode average linkage (Kaufman dan
Rousseeuw, 1990). Perangkat lunak yang digunakan adalah R 3.2.0.

\section{HASIL DAN PEMBAHASAN}

\section{Keragaan Sifat Kualitatif}

Karakter kualitatif pada Tabel 1 menunjukkan adanya perbedaan karakter buah berdasarkan juring, intensitas jala, dan distribusi jala. Genotipe P7, P12, dan P18 memiliki juring pada permukaan buahnya sedangkan yang lainnya tidak. Genotipe melon pada kelompok varietas inodorus (P7, P18, P19, P27, P29, P31, dan P34 (IPB Meta-9)) tidak memiliki jala pada permukaan buahnya, lain halnya dengan genotipe melon pada kelompok varietas reticulatus ( $\mathrm{P} 2, \mathrm{P} 3, \mathrm{P} 5, \mathrm{P} 9$, P10, P12, P21, P23, P25, dan P26).

Karakter kualitatif umumnya dikendalikan oleh gen sederhana (satu atau dua gen) dan sangat sedikit dipengaruhi oleh faktor lingkungan (Syukur et al., 2012). Tingkat keragaman melon juga diamati berdasarkan bentuk buah, warna buah, warna daging, dan tekstur (Tabel 1 dan Gambar 1). Karakter warna buah dan warna daging buah masih menunjukkan adanya keragaman di dalam genotipe (Gambar 2). Genotipe P3 dan P31 masih memiliki keragaman di dalam genotipe untuk karakter warna kulit buah dan warna daging buah, sedangkan genotipe P2, P27, P34, dan P7 memiliki tingkat keseragaman yang lebih tinggi (Gambar 3). Perbedaan tingkat keseragaman di dalam genotipe kemungkinan disebabkan oleh bahan genetik dalam penelitian yang masih berupa genotipe seleksi atau telah berada pada generasi akhir menuju tahap penggaluran. Menurut Syukur et al. (2012) pada tanaman tipe menyerbuk silang seperti melon memiliki tingkat heterozigositas yang cukup tinggi. 
Tabel 1. Juring, intensitas jala, dan distribusi jala genotipe melon

\begin{tabular}{|c|c|c|c|c|c|c|c|}
\hline Genotipe & Juring & $\begin{array}{l}\text { Intensitas } \\
\text { Jala } \\
\text { (skor 1-5) }\end{array}$ & Distribusi Jala & $\begin{array}{l}\text { Bentuk } \\
\text { Buah }\end{array}$ & $\begin{array}{c}\text { Warna } \\
\text { Permukaan } \\
\text { Buah }\end{array}$ & $\begin{array}{c}\text { Warna } \\
\text { Daging } \\
\text { Buah }\end{array}$ & Tekstur \\
\hline $\mathrm{P} 2$ & tidak ada & 5 & $\begin{array}{l}\text { menyebar } \\
\text { penuh }\end{array}$ & flattened & oranye & oranye & lembut \\
\hline P3 & tidak ada & 5 & $\begin{array}{l}\text { menyebar } \\
\text { penuh }\end{array}$ & globular & hijau tua & $\begin{array}{l}\text { putih- } \\
\text { hijau } \\
\text { muda, } \\
\text { oranye }\end{array}$ & lembut \\
\hline P5 & tidak ada & 2 & $\begin{array}{c}\text { menyebar } \\
\text { pada satu sisi }\end{array}$ & globular & hijau tua & oranye & lembut \\
\hline P7 & ada & 1 & tidak ada & ellips & kuning & oranye & renyah \\
\hline P9 & tidak ada & 3 & $\begin{array}{l}\text { menyebar } \\
\text { penuh }\end{array}$ & globular & $\begin{array}{l}\text { putih, } \\
\text { kuning, } \\
\text { hijau }\end{array}$ & putih & renyah \\
\hline P10 & tidak ada & 5 & $\begin{array}{l}\text { menyebar } \\
\text { penuh }\end{array}$ & globular & hijau tua & oranye & kenyal \\
\hline P12 & ada & 2 & $\begin{array}{c}\text { menyebar } \\
\text { pada satu sisi }\end{array}$ & oblate & $\begin{array}{l}\text { hijau tua- } \\
\text { oranye }\end{array}$ & putih & renyah \\
\hline P18 & ada & 1 & tidak ada & globular & $\begin{array}{l}\text { kuning-hijau } \\
\text { muda }\end{array}$ & putih & renyah \\
\hline P19 & tidak ada & 1 & tidak ada & globular & putih & putih & renyah \\
\hline $\mathrm{P} 21$ & tidak ada & 3 & $\begin{array}{l}\text { menyebar } \\
\text { pada satu sisi }\end{array}$ & globular & kuning & putih & lembut \\
\hline $\mathrm{P} 23$ & tidak ada & 2 & $\begin{array}{l}\text { menyebar } \\
\text { pada satu sisi }\end{array}$ & flattened & kuning & $\begin{array}{l}\text { hijau } \\
\text { muda- } \\
\text { putih }\end{array}$ & lembut \\
\hline $\mathrm{P} 25$ & tidak ada & 5 & $\begin{array}{l}\text { menyebar } \\
\text { penuh }\end{array}$ & globular & $\begin{array}{l}\text { hijau muda- } \\
\text { putih }\end{array}$ & $\begin{array}{l}\text { hijau } \\
\text { muda- } \\
\text { putih }\end{array}$ & renyah \\
\hline $\mathrm{P} 26$ & tidak ada & 3 & $\begin{array}{l}\text { menyebar } \\
\text { sebagian }\end{array}$ & globular & $\begin{array}{l}\text { hijau muda- } \\
\text { putih }\end{array}$ & $\begin{array}{l}\text { putih- } \\
\text { hijau } \\
\text { muda }\end{array}$ & kenyal \\
\hline $\mathrm{P} 27$ & tidak ada & 1 & tidak ada & ellips & kuning & oranye & renyah \\
\hline P29 & tidak ada & 1 & tidak ada & ellips & kuning & oranye & renyah \\
\hline P31 & tidak ada & 1 & tidak ada & ellips & $\begin{array}{l}\text { putih, } \\
\text { kuning }\end{array}$ & $\begin{array}{l}\text { putih, } \\
\text { oranye }\end{array}$ & renyah \\
\hline P34 & tidak ada & 1 & tidak ada & ovate & oranye & putih & renyah \\
\hline
\end{tabular}

Keterangan: Skor intensitas jala 1: tidak ada jala (0\%); 2: sangat sedikit (10-25\%); 3: sedang (26-50); 4: agak banyak (50-75); 5: (76-100\%) sangat banyak. 


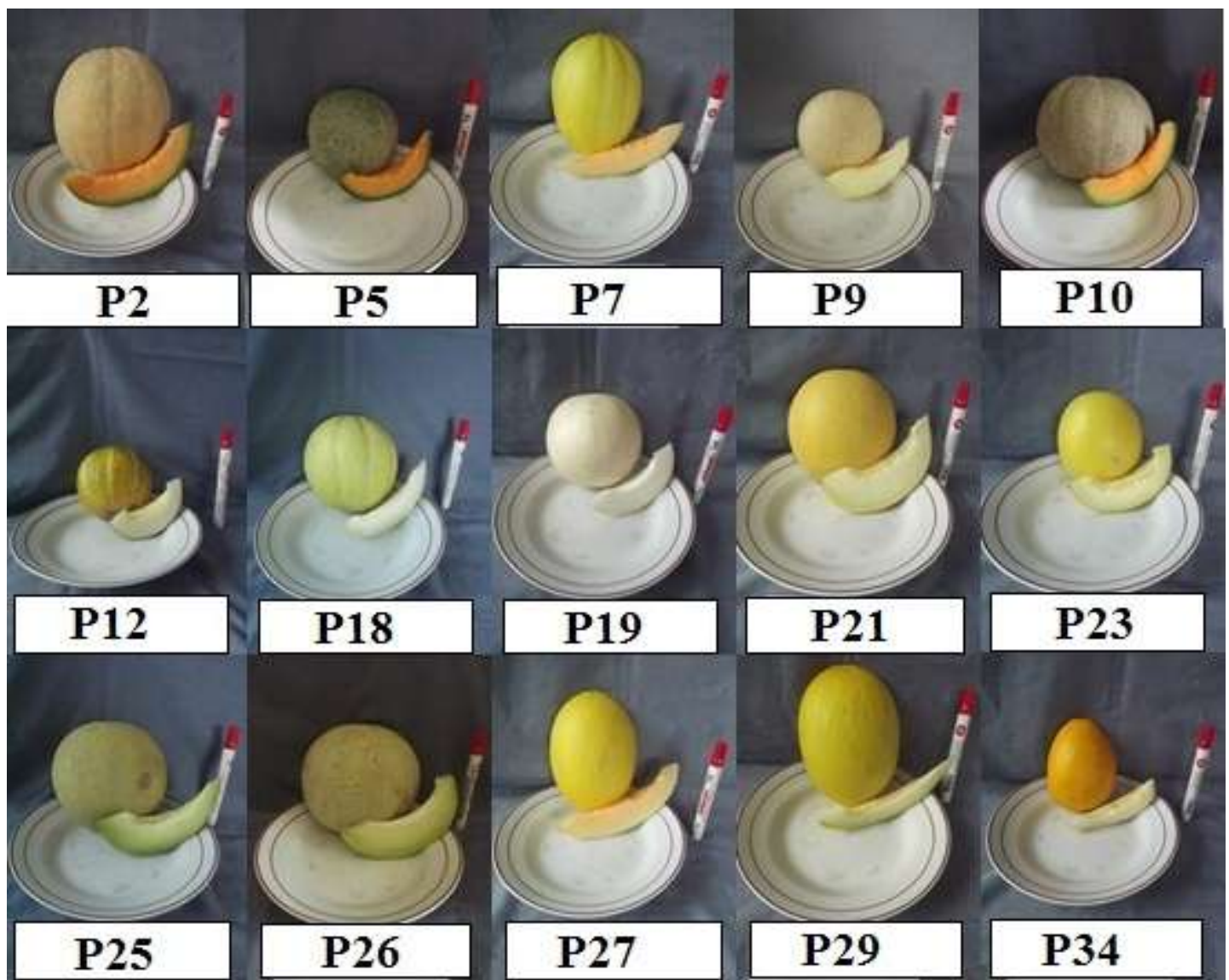

Gambar 1. Keragaan genotipe 15 melon yang memiliki keseragaman di dalam genotipe

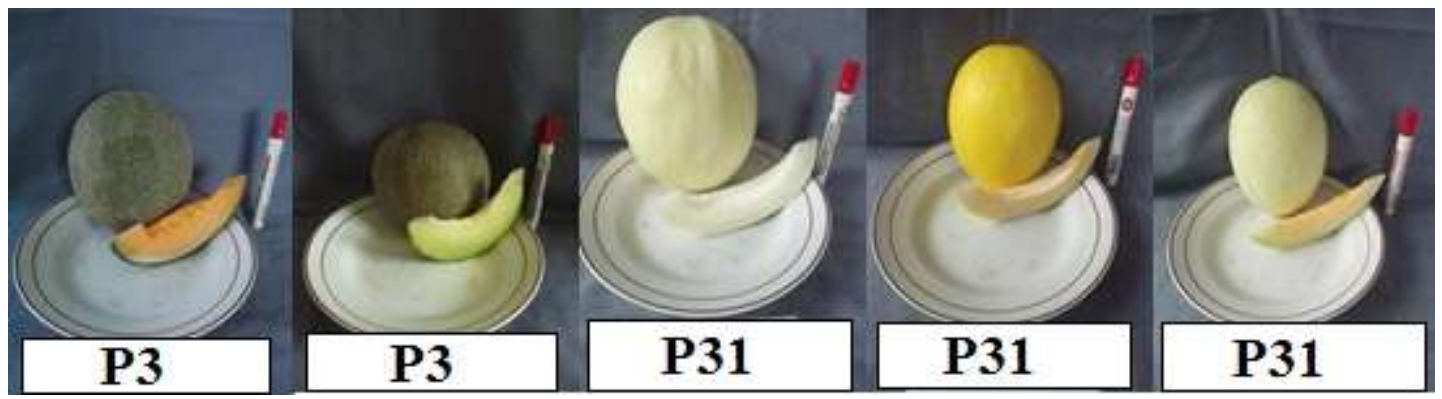

Gambar 2. Keragaan genotipe P3 dan P31 yang memiliki keragaman di dalam genotipe

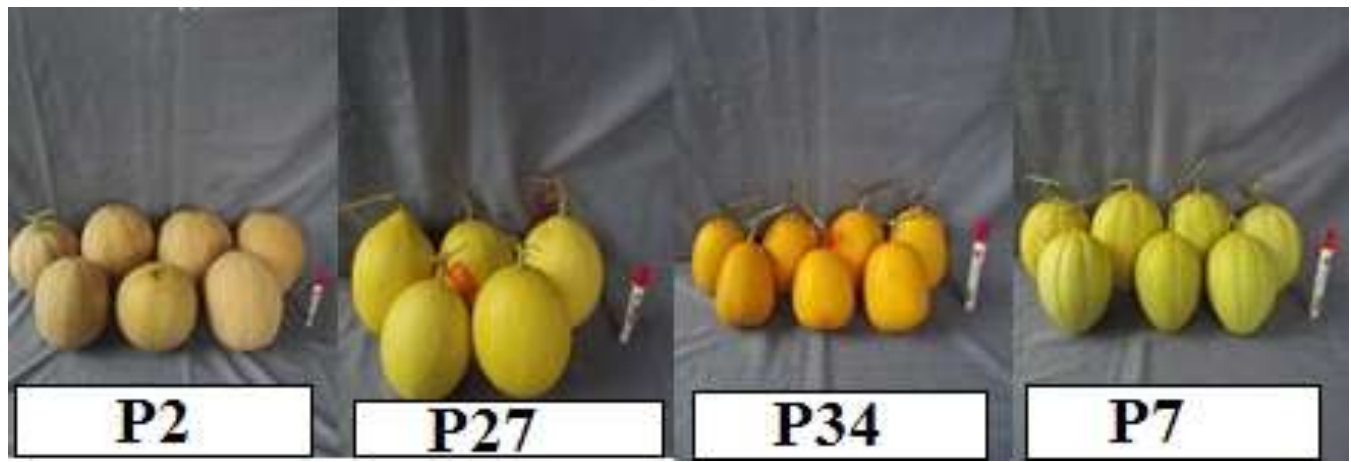

Gambar 3. Keragaan genotipe yang seragam 


\section{Keragaan Sifat Kuantitatif}

Pengaruh genotipe nyata terhadap semua karakter kecuali umur berbunga hermaprodit (Tabel 2). Karakter kuantitatif umumnya dikendalikan oleh banyak gen serta dipengaruhi oleh lingkungan (Syukur et al., 2012). Umur panen dipengaruhi oleh ketinggian tempat, dimana pada dataran rendah umumnya melon lebih cepat panen dibandingkan pada dataran menengah dan tinggi (Afandi, 2013). Pengaruh ulangan umumnya tidak nyata pada taraf 5\% terhadap semua karakter yang diamati kecuali umur berbunga hermaprodit dan umur panen (Tabel 2). Karakter umur memiliki nilai koefisien keragaman (KK) yang lebih kecil (2.50$6.62 \%)$ dibandingkan dengan hasil dan komponennya (6.35-18.87\%), menandakan bahwa keragaan karakter hasil lebih dipengaruhi oleh lingkungan mikro dibandingkan dengan karakter umur.

Genotipe P7 merupakan genotipe yang memiliki umur berbunga jantan tercepat, yaitu 19 HST, sedangkan P12 dan P34 memiliki umur berbunga jantan terlama, yaitu 24 HST (Tabel 3).

Umur berbunga hermaprodit berkisar antara 30-35 HST. Genotipe P34 memiliki umur panen tercepat, yaitu 62 HST sedangkan genotipe P10 dan P26 memiliki umur panen terlama, yaitu 70 HST. Genotipe yang memiliki nilai panjang dan diameter buah terbesar adalah P2, yaitu $15.08 \mathrm{~cm}$ dan 13.91 $\mathrm{cm}$ (Tabel 3). Genotipe P34 memiliki panjang buah $11.13 \mathrm{~cm}$ dan diameter buah $8.48 \mathrm{~cm}$. Keragaman pada panjang buah juga ditunjukkan pada $C$. melo L. var. flexuosus yang memiliki panjang buah mencapai 150 $\mathrm{cm}$, sedangkan C. melo L. var. agrestis hanya memiliki panjang $4 \mathrm{~cm}$ (Nuñez-Palenius et al., 2008).

Daging buah (bagian yang dapat dikonsumsi) yang tertebal dimiliki oleh genotipe P21 $(2.90 \mathrm{~cm})$, sedangkan yang tertipis adalah P34 $(1.31 \mathrm{~cm})$. Kulit buah tertebal dimiliki oleh genotipe P2 $(0.96 \mathrm{~cm})$, sedangkan genotipe P34 memiliki kulit buah tertipis $(0.36 \mathrm{~cm})$ (Tabel 4$)$. Nilai tengah bobot buah tertinggi dimiliki oleh genotipe P2, yaitu $1555.20 \mathrm{~g}$, sedangkan P34 memiliki bobot terendah yaitu $442.10 \mathrm{~g}$ (Tabel 4). Menurut Khumaero et al. (2014) melon dengan bobot buah kecil merupakan potensi untuk tipe buah yang dikonsumsi pribadi dan dapat dihabiskan pada satu atau dua kesempatan. Kadar gula tertinggi dimilki oleh genotipe P12, yaitu 10.88 ${ }^{\circ}$ Brix, sedangkan P2 memiliki kadar gula terendah, yaitu $6.41{ }^{\circ}$ Brix (Tabel 4). Pada pemuliaan melon, terdapat dua karakter buah yang penting yaitu bobot buah dan kadar gula. Hal tersebut sesuai dengan Suketi et al. (2010) bahwa langkah awal dalam pemuliaan tanaman buah umumnya dimulai dari penentuan kriteria buah yang diinginkan, diantaranya adalah yang memiliki bobot buah dan kadar gula tinggi. Pada daging buah melon, sukrosa memiliki korelasi positif dan nyata dengan kadar gula total $(\mathrm{r}=0.92)$, demikian pula dengan glukosa $(\mathrm{r}=0.89)$ dan fruktosa $(\mathrm{r}=0.84)$ (Obando-Ulloa et al., 2009). Menurut Oh et al. (2011) pada melon tipe jala terdapat adanya peningkatan kandungan volatil selama tahap pertumbuhan, pematangan, hingga pemasakan buah. Menurut Liu et al. (2004) melon tipe inodorus memiliki daya simpan yang lebih panjang dibandingkan dengan melon tipe reticulatus dan cantalupensis, dan menurut Manohar dan Murthy (2012) terdapat korelasi antara daya simpan dengan tebal daging buah $(\mathrm{r}=0.54)$.

Tabel 2. Rekapitulasi sidik ragam karakter melon

\begin{tabular}{|c|c|c|c|}
\hline Karakter & KT Genotipe & KT Ulangan & KK $(\%)$ \\
\hline Umur berbunga jantan & $6.62^{* *}$ & $0.91^{\mathrm{tn}}$ & 6.62 \\
\hline Umur berbunga hermaprodit & $3.21^{\mathrm{tn}}$ & $9.37^{*}$ & 5.17 \\
\hline Umur panen & $18.65^{\text {** }}$ & $13.10^{* *}$ & 2.50 \\
\hline Panjang buah & $5.80^{* * *}$ & $0.19^{\mathrm{tn}}$ & 8.69 \\
\hline Diameter buah & $5.52^{* *}$ & $0.60^{\mathrm{tn}}$ & 6.35 \\
\hline Tebal daging buah & $0.31^{* *}$ & $0.04^{\mathrm{tn}}$ & 9.33 \\
\hline Tebal kulit buah & $0.12^{* *}$ & $0.01^{\mathrm{tn}}$ & 14.06 \\
\hline Bobot buah & $223247.32^{* * *}$ & $13387.22^{\text {tn }}$ & 18.87 \\
\hline Kadar gula & $3.60^{* *}$ & $0.65^{\mathrm{tn}}$ & 13.92 \\
\hline
\end{tabular}


Tabel 3. Rata-rata umur berbunga jantan, umur berbunga hermaprodit, umur panen, panjang buah, dan diameter buah 17 genotipe melon

\begin{tabular}{llcccc}
\hline \multirow{2}{*}{ Genotipe } & \multicolumn{5}{c}{ Karakter } \\
\cline { 2 - 6 } & $\begin{array}{c}\text { Umur Berbunga } \\
\text { Jantan (HST) }\end{array}$ & $\begin{array}{c}\text { Umur Berbunga } \\
\text { Hermaprodit (HST) }\end{array}$ & $\begin{array}{c}\text { Umur Panen } \\
(\text { HST })\end{array}$ & $\begin{array}{c}\text { Panjang Buah } \\
(\mathrm{cm})\end{array}$ & $\begin{array}{c}\text { Diameter } \\
\text { Buah }(\mathrm{cm})\end{array}$ \\
\hline P2 & $22 \mathrm{abcde}$ & $33 \mathrm{abc}$ & $65 \mathrm{bcd}$ & $15.80 \mathrm{a}$ & $13.91 \mathrm{a}$ \\
P3 & $20 \mathrm{def}$ & $30 \mathrm{c}$ & $67 \mathrm{ab}$ & $12.61 \mathrm{bcde}$ & $13.15 \mathrm{abc}$ \\
P5 & $20 \mathrm{ef}$ & $33 \mathrm{abc}$ & $63 \mathrm{~cd}$ & $12.52 \mathrm{bcde}$ & $11.32 \mathrm{efg}$ \\
P7 & $19 \mathrm{f}$ & $33 \mathrm{abc}$ & $64 \mathrm{~cd}$ & $13.94 \mathrm{a}$ & $10.34 \mathrm{~g}$ \\
P9 & $20 \mathrm{def}$ & $33 \mathrm{abc}$ & $64 \mathrm{~cd}$ & $11.68 \mathrm{cde}$ & $10.96 \mathrm{efg}$ \\
P10 & $20 \mathrm{def}$ & $32 \mathrm{bc}$ & $70 \mathrm{a}$ & $10.48 \mathrm{e}$ & $11.72 \mathrm{defg}$ \\
P12 & $24 \mathrm{a}$ & $32 \mathrm{abc}$ & $69 \mathrm{a}$ & $10.69 \mathrm{e}$ & $11.38 \mathrm{efg}$ \\
P18 & $21 \mathrm{bcdef}$ & $32 \mathrm{abc}$ & $69 \mathrm{a}$ & $13.04 \mathrm{bcd}$ & $11.82 \mathrm{cdef}$ \\
P19 & $21 \mathrm{cdef}$ & $32 \mathrm{abc}$ & $65 \mathrm{bc}$ & $13.32 \mathrm{bc}$ & $12.21 \mathrm{bcde}$ \\
P21 & $21 \mathrm{bcdef}$ & $35 \mathrm{ab}$ & $66 \mathrm{bc}$ & $12.92 \mathrm{bcd}$ & $12.22 \mathrm{bcde}$ \\
P23 & $21 \mathrm{cdef}$ & $33 \mathrm{abc}$ & $66 \mathrm{bc}$ & $12.90 \mathrm{bcd}$ & $10.82 \mathrm{efg}$ \\
P25 & $22 \mathrm{abcd}$ & $33 \mathrm{abc}$ & $69 \mathrm{a}$ & $12.35 \mathrm{bcde}$ & $13.02 \mathrm{abcd}$ \\
P26 & $23 \mathrm{abc}$ & $34 \mathrm{ab}$ & $70 \mathrm{a}$ & $13.23 \mathrm{bcd}$ & $13.29 \mathrm{ab}$ \\
P27 & $21 \mathrm{bcdef}$ & $33 \mathrm{abc}$ & $64 \mathrm{bcd}$ & $13.86 \mathrm{ab}$ & $10.35 \mathrm{~g}$ \\
P29 & $20 \mathrm{def}$ & $33 \mathrm{abc}$ & $65 \mathrm{bcd}$ & $14.21 \mathrm{ab}$ & $10.42 \mathrm{fg}$ \\
P31 & $21 \mathrm{bcdef}$ & $34 \mathrm{ab}$ & $65 \mathrm{bcd}$ & $14.17 \mathrm{ab}$ & $11.12 \mathrm{efg}$ \\
P34 & $24 \mathrm{ab}$ & $35 \mathrm{a}$ & $62 \mathrm{~d}$ & $11.13 \mathrm{de}$ & $8.48 \mathrm{~h}$ \\
\hline
\end{tabular}

Keterangan: Angka-angka yang diikuti huruf yang sama pada kolom yang sama tidak berbeda nyata berdasarkan uji lanjut DMRT pada taraf 5\%.

Tabel 4. Rata-rata tebal daging buah, tebal kulit buah, bobot buah, dan kadar gula 17 genotipe melon

\begin{tabular}{lllcc}
\hline \multirow{2}{*}{ Genotipe } & \multicolumn{3}{c}{ Karakter } \\
\cline { 2 - 5 } & $\begin{array}{c}\text { Tebal Daging } \\
\text { Buah }(\mathrm{cm})\end{array}$ & $\begin{array}{c}\text { Tebal Kulit } \\
\text { Buah }(\mathrm{cm})\end{array}$ & $\begin{array}{c}\text { Bobot Buah } \\
(\mathrm{g})\end{array}$ & $\begin{array}{c}\text { Kadar Gula } \\
\left({ }^{\circ} \mathrm{Brix}\right)\end{array}$ \\
\hline P2 & $2.31 \mathrm{bcde}$ & $0.96 \mathrm{a}$ & $1555.20 \mathrm{a}$ & $6.41 \mathrm{c}$ \\
P3 & $2.83 \mathrm{a}$ & $0.75 \mathrm{bc}$ & $1198.90 \mathrm{bc}$ & $7.64 \mathrm{bc}$ \\
P5 & $2.18 \mathrm{cde}$ & $0.63 \mathrm{cde}$ & $859.50 \mathrm{de}$ & $8.13 \mathrm{bc}$ \\
P7 & $2.15 \mathrm{cde}$ & $0.38 \mathrm{gh}$ & $723.20 \mathrm{ef}$ & $7.54 \mathrm{bc}$ \\
P9 & $2.51 \mathrm{abcd}$ & $0.53 \mathrm{defg}$ & $782.50 \mathrm{de}$ & $9.45 \mathrm{ab}$ \\
P10 & $2.16 \mathrm{cde}$ & $0.86 \mathrm{ab}$ & $806.40 \mathrm{de}$ & $6.71 \mathrm{c}$ \\
P12 & $2.52 \mathrm{abcd}$ & $0.64 \mathrm{~cd}$ & $773.80 \mathrm{de}$ & $10.88 \mathrm{a}$ \\
P18 & $2.13 \mathrm{de}$ & $0.67 \mathrm{~cd}$ & $893.40 \mathrm{cde}$ & $8.58 \mathrm{bc}$ \\
P19 & $2.55 \mathrm{abc}$ & $0.60 \mathrm{cde}$ & $1087.10 \mathrm{bcd}$ & $8.44 \mathrm{bc}$ \\
P21 & $2.90 \mathrm{a}$ & $0.57 \mathrm{def}$ & $1083.60 \mathrm{bcd}$ & $9.23 \mathrm{ab}$ \\
P23 & $2.15 \mathrm{cde}$ & $0.50 \mathrm{defgh}$ & $793.60 \mathrm{de}$ & $8.15 \mathrm{bc}$ \\
P25 & $2.62 \mathrm{ab}$ & $0.85 \mathrm{ab}$ & $1100.20 \mathrm{bcd}$ & $8.04 \mathrm{bc}$ \\
P26 & $2.51 \mathrm{abcd}$ & $0.96 \mathrm{a}$ & $1233.60 \mathrm{~b}$ & $7.61 \mathrm{bc}$ \\
P27 & $2.08 \mathrm{e}$ & $0.43 \mathrm{fgh}$ & $731.80 \mathrm{ef}$ & $8.50 \mathrm{bc}$ \\
P29 & $2.10 \mathrm{de}$ & $0.47 \mathrm{efgh}$ & $723.10 \mathrm{ef}$ & $7.54 \mathrm{bc}$ \\
P31 & $2.28 \mathrm{bcde}$ & $0.53 \mathrm{defg}$ & $877.00 \mathrm{cde}$ & $8.53 \mathrm{bc}$ \\
P34 & $1.31 \mathrm{f}$ & $0.36 \mathrm{~h}$ & $442.10 \mathrm{f}$ & $9.74 \mathrm{ab}$ \\
\hline
\end{tabular}

Keterangan: Angka-angka yang diikuti huruf yang sama pada kolom yang sama tidak berbeda nyata berdasarkan uji lanjut DMRT pada taraf 5\%. 
Tabel 5. Nilai duga komponen ragam dan nilai heritabilitas arti luas

\begin{tabular}{lrrrr}
\hline \multicolumn{1}{c}{ Karakter } & $\mathrm{V}_{\mathrm{g}}$ & $\mathrm{V}_{\mathrm{e}}$ & \multicolumn{1}{c}{$\mathrm{V}_{\mathrm{p}}$} & $\mathrm{h}_{\text {bs }}^{2}(\%)$ \\
\hline Umur berbunga jantan & 1.49 & 1.88 & 1.96 & 75.99 \\
Umur panen & 5.18 & 2.75 & 5.86 & 88.28 \\
Panjang buah & 1.45 & 1.20 & 1.75 & 82.81 \\
Diameter buah & 1.60 & 0.54 & 1.74 & 92.26 \\
Tebal daging & 0.11 & 0.05 & 0.12 & 90.02 \\
Tebal kulit & 0.03 & 0.01 & 0.04 & 94.46 \\
Bobot buah & 58376.00 & 30085.00 & 65897.25 & 88.59 \\
Kadar gula & 0.75 & 1.28 & 1.07 & 70.08 \\
\hline
\end{tabular}

Keterangan: $\mathrm{V}_{\mathrm{g}}$ : ragam genetik; $\mathrm{V}_{\mathrm{e}}$ : ragam lingkungan; $\mathrm{V}_{\mathrm{p}}$ : ragam fenotipik $; \mathrm{h}^{2}{ }_{\text {bs-: }}$ nilai heritabilitas arti luas

\section{Pendugaan Komponen Ragam dan Heritabilitas Arti Luas}

Pendugaan komponen ragam digunakan dalam studi genetika untuk sifat kuantitatif. Heritabilitas merupakan penentu proporsi variabilitas total yang disebabkan oleh genetik, atau rasio ragam genetik terhadap ragam total. Heritabilitas arti luas $\left(\mathrm{h}_{\mathrm{bs}}^{2}\right)$ merupakan rasio antara ragam genetik dengan ragam fenotipik (Syukur et al., 2012).

Karakter tebal kulit merupakan karakter yang memiliki nilai heritabilitas tertinggi, yaitu $94.46 \%$. Karakter bobot dan kadar gula memiliki nilai heritabilitas $88.59 \%$ dan $70.08 \%$ (Tabel 5). Nilai $\mathrm{h}_{\text {bs }}^{2}>50 \%$ termasuk dalam kategori tinggi, 30-50\% adalah sedang, dan $<30 \%$ adalah rendah. Menurut Jhonson et al. (2009) karakter yang memiliki nilai heritabilitas $>50 \%$ dimungkinkan untuk digunakan sebagai karakter seleksi. Pendugaan komponen ragam dalam menentukan nilai heritabilitas arti luas karakter bobot buah (99.36\%), panjang buah (99.56\%), dan diameter buah (97.82\%) menunjukkan nilai yang tinggi (Ibrahim, 2012). Nilai heritabilitas arti luas bobot buah pada percobaan yang dilakukan Zalapa et al. (2006) adalah $81 \%$, sedangkan heritabilitas arti sempit adalah $45 \%$. Selain karakter buah, pada penelitian yang dilakukan oleh Shashikumar et al. (2010) nilai heritabilitas arti luas untuk ketahanan terhadap penyakit downy mildew tergolong tinggi, yaitu $88 \%$ pada percobaan di lapang dan $81 \%$ pada percobaan di green house. Namun demikian, nilai ragam interaksi genotipexlingkungan tidak dapat dipelajari dalam penelitian ini, karena percobaan yang dilakukan hanya pada satu musim, sehingga ragam genetik dan heritabilitas berpotensi untuk terestimasi-lebih (overestimated) dari nilai yang sebenarnya.

\section{Seleksi Simultan Berdasarkan Bobot Buah dan Kadar Gula}

Seleksi simultan melibatkan dua karakter atau lebih yang dinilai penting. Karakter bobot buah dan kadar gula digunakan sebagai kriteria seleksi secara simultan untuk mengidentifikasi genotipe-genotipe potensial. Hasil seleksi menunjukkan bahwa genotipe yang memiliki potensi untuk sifat bobot buah dan kadar gula tinggi adalah genotipe P21 dan P19. Selain itu genotipe P2 memiliki potensi yang baik untuk karakter bobot buah, meskipun kadar gulanya relatif rendah, dan genotipe P12 memiliki potensi baik untuk karakter kadar gula, namun bobot buahnya relatif rendah (Gambar 4). Hal serupa dikemukakan oleh Szamosi et al. (2010) dimana kultivar melon Hungaria memiliki kadar gula yang lebih tinggi $\left(9.8{ }^{\circ}\right.$ Brix $)$ dibandingkan dengan kultivar melon Turki (7.4 ${ }^{\circ}$ Brix), tetapi keduanya tidak memiliki perbedaan yang signifikan pada karakter bobot buah, yaitu $1333.7 \mathrm{~g}$ dan $1017.7 \mathrm{~g}$. Hal ini menjadi menarik dalam pemuliaan melon ke depan karena dapat diduga bahwa gen pengendali kedua faktor kualitas buah tersebut tidak terkait, sehingga memungkinkan perakitan melon yang memiliki ukuran buah kecil maupun besar dengan rasa manis sesuai dengan selera konsumen. 


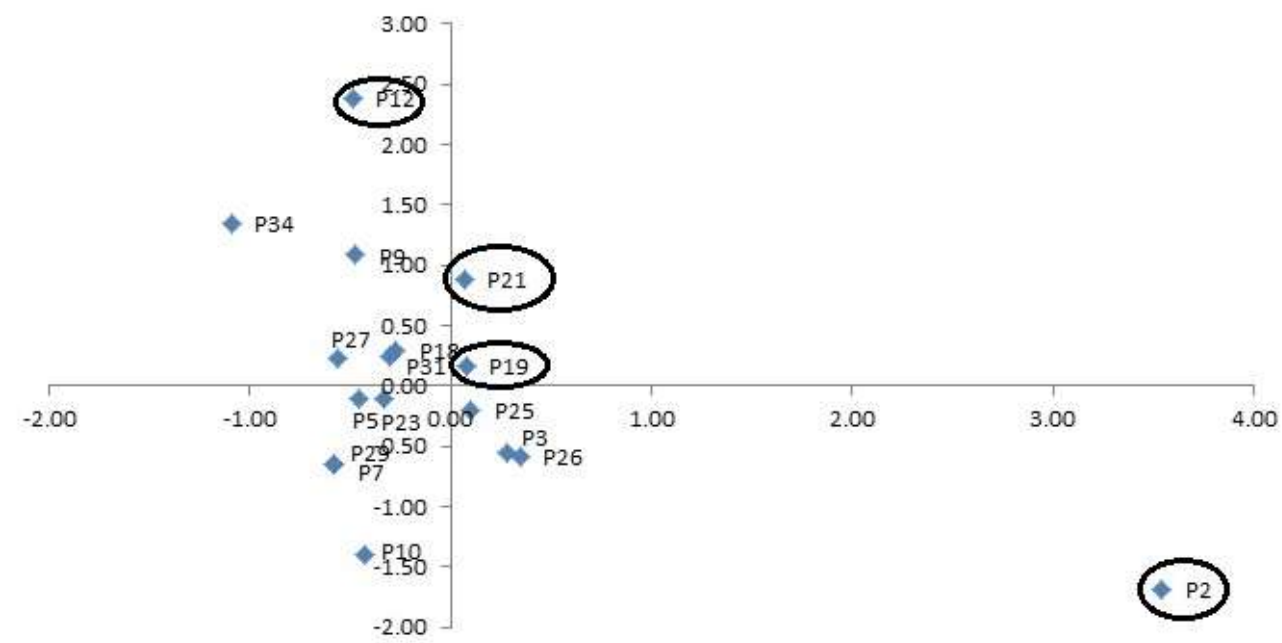

Gambar 4. Seleksi simultan 17 genotipe melon. Sumbu $X$ adalah rata-rata bobot buah yang terstandarisasi dan sumbu $\mathrm{Y}$ adalah rata-rata kadar gula yang terstandarisasi

\section{Keeratan Hubungan Antar Karakter}

Karakter bobot buah memiliki korelasi positif dan sangat nyata dengan karakter panjang buah $(\mathrm{r}=0.59, \mathrm{P}<0.01)$, diameter buah $(\mathrm{r}=0.93, \mathrm{P}<0.01)$, tebal daging buah $(\mathrm{r}=0.64, \mathrm{P}<0.01)$, dan tebal kulit buah $(\mathrm{r}=0.76, \mathrm{P}<0.01)$ (Tabel 6). Hal ini sesuai dengan percobaan yang dilakukan oleh Wang et al. (2016) dimana bobot buah berkorelasi dengan diameter buah, panjang buah, dan tebal kulit buah pada percobaan yang dilakukan pada dua musim. Rata-rata bobot per buah memiliki korelasi negatif $(r=-0.76, \mathrm{P}<0.01)$ dengan jumlah buah per tanaman (Zalapa et al. 2008). Melon tipe inodorus dalam penelitian ini umumnya memiliki rata-rata kulit buah yang relatif lebih tipis $(0.49 \mathrm{~cm})$ dibandingkan dengan melon tipe reticulatus dan cantalupensis $(0.73 \mathrm{~cm})$, namun rata-rata kadar gula kedua tipe tersebut hampir sama (8.41 dan $8.33{ }^{\circ}$ Brix). Analisis korelasi menunjukkan adanya hubungan negatif antara tebal kulit buah dan kadar gula namun koefisien korelasinya rendah $(\mathrm{r}=-0.30$, $\mathrm{P}<0.05$ ). Menurut Paris et al. (2008) tingkat kekerasan kulit buah melon berkorelasi negatif dengan kadar gula $(\mathrm{r}=-0.24, \quad \mathrm{P}<0.05)$. Karakter panjang buah berkorelasi positif dengan diameter buah $(\mathrm{r}=0.37, \mathrm{P}<0.01)$. Menurut Malik et al. (2014), pengujian terhadap C. melo subsp. agrestis grup momordica dan $C$. melo subsp. melo grup cantalupensis dan reticulatus menunjukkan korelasi nyata antara kandungan gula dengan tebal kulit buah $(\mathrm{r}=0.65)$.

Tabel 6. Koefisien korelasi linier antarkarakter pada genotipe melon

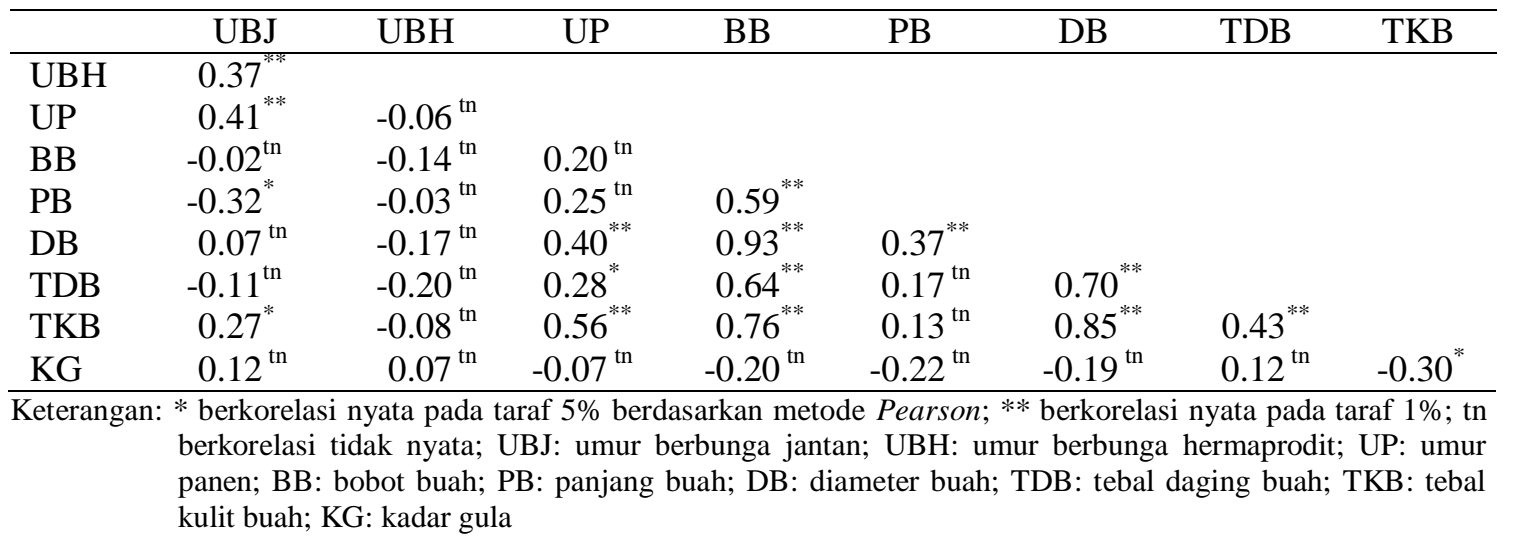




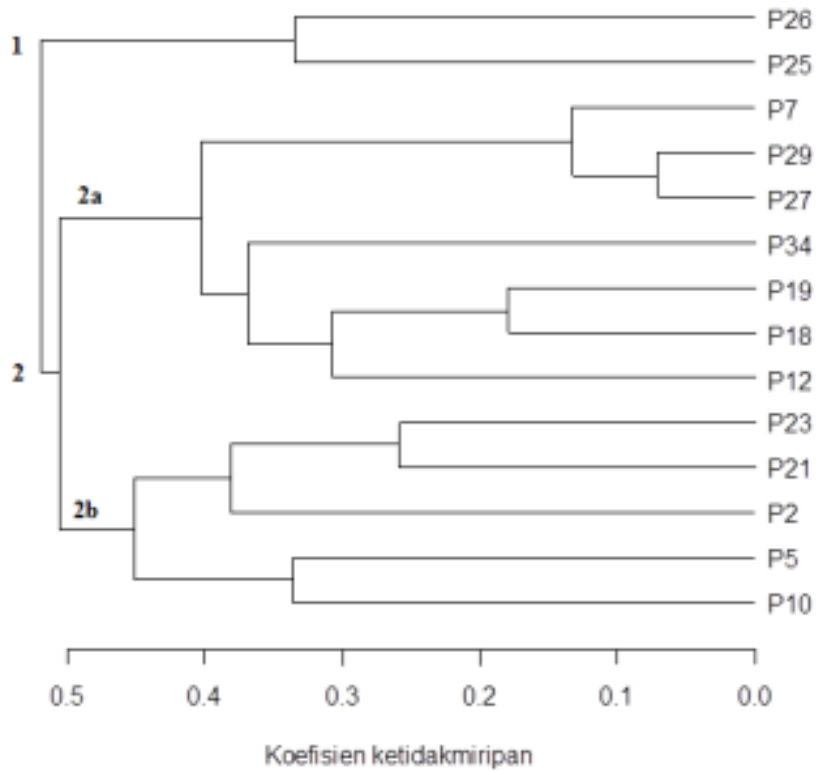

Gambar 5. Dendrogram 14 genotipe melon hasil analisis gerombol berdasarkan karakter kuantitatif dan kualitatif

\section{Pengelompokan Genotipe}

Analisis gerombol dilakukan pada 14 genotipe melon berdasarkan 9 peubah kuantitatif dan 15 peubah kualitatif yang menunjukkan keseragaman di dalam genotipe (Gambar 5). Nilai koefisien ketidakmiripan yang semakin besar menunjukan adanya perbedaan genetik yang semakin jauh antar genotipe. Pada koefisien ketidakmiripan sekitar 0.52, terdapat dua kelompok. Kelompok pertama berisi genotipe P25 dan P26 yang memiliki ciri-ciri tipe reticulatus (berjala) dan keragaan buah yang sangat mirip (Gambar 1). Kelompok kedua umumnya merupakan genotipe yang memiliki ciri-ciri tipe inodorus (tidak berjala) dan sebagian reticulatus (berjala) lainnya, yang selanjutnya dapat dikelompokkan lagi menjadi kelompok $2 \mathrm{a}$ dan $2 \mathrm{~b}$ pada koefisien ketidakmiripan sekitar 0.50. Kelompok 2a berisi genotipegenotipe dengan tipe inodorus (kecuali P12), sedangkan $2 \mathrm{~b}$ berisi genotipe-genotipe dengan tipe reticulatus. Ning et al. (2014) melaporkan bahwa pengelompokkan kultivar melon Hami di Cina dengan marker SSR dibagi menjadi dua kelompok besar, yaitu melon dengan tipe kulit buah tipis dan tebal.
Menurut Robinson dan Decker (1999) melon dikelompokan menjadi dua grup, yaitu grup C. melo var. cantalupensis atau reticulatus dan grup C. melo var. inodorus. Kelompok cantalupensis (nama yang umum adalah cantaloupe dan muskmelon) memiliki ciri-ciri yaitu, buah yang berukuran sedang dan berjala, daging buah umumnya berwarna oranye, namun ada juga yang berwarna hijau, dan tangkai buahnya lepas saat masak. Kelompok inodorus memiliki karakteristik yaitu, permukaan buah tidak berjala, daya simpan buah relatif lama, dan tangkai buahnya tidak lepas saat masak.

\section{KESIMPULAN}

Genotipe melon yang diuji menunjukkan adanya keragaman berdasarkan karakter morfologi kecuali karakter umur berbunga hermaprodit. Genotipe yang memiliki potensi terhadap karakter bobot buah dan kadar gula tinggi adalah genotipe P21 (1 083.60 g dan $9.23{ }^{\circ}$ Brix) dan P19 (1 087.10 $\mathrm{g}$ dan $8.44{ }^{\circ}$ Brix). Selain itu, genotipe P2 memiliki potensi yang baik untuk karakter bobot (1 $555.20 \mathrm{~g}$ ) dan genotipe P12 (10.88 ${ }^{\circ}$ Brix) memiliki potensi baik untuk karakter kadar gula yang tinggi. Semua karakter yang 
diuji memiliki nilai heritabilitas arti luas lebih dari 50\%. Pengelompokan berdasarkan karakter morfologi umumnya menunjukkan bahwa genotipe melon reticulatus dan inodorus berada pada grup yang berbeda.

\section{UCAPAN TERIMA KASIH}

Terima kasih disampaikan kepada Ahmad Kurniawan dan seluruh teknisi Kebun Percobaan PKHT IPB Tajur II, Bogor Selatan, atas bantuannya dalam pelaksanaan percobaan. Penelitian ini dibiayai dari Hibah Penelitian Strategis Nasional, Kementerian Riset, Teknologi, dan Pendidikan Tinggi Republik Indonesia.

\section{DAFTAR PUSTAKA}

Afandi, M.A., R. Sulistyo, N. Herlina. 2013. Respon pertumbuhan dan hasil lima varietas melon (Cucumis melo L.) pada tiga ketinggian tempat. J. Produksi Tanaman. 1(4): 342-352.

[BBI IRRI] Biometrics and Breeding Informatics IRRI. 2017. Statistical Tool For Agricultural Research. http://bbi. rri.org/.

[BPS] Badan Pusat Statistik Republik Indonesia. 2016. Produksi tanaman buah-buahan. https://www.bps.go.id/ site/resultTab.

[IPGRI] International Plant Genetic Resources Institute. 2003. Description for melon (Cucumis melo L.). 92-9043-597-7.

Jhonson, M.T.J., A.A. Agrawal, J.L. Maron, J.P. Salminen. 2009. Heritability, covariation and natural selection on 24 traits of common evening primrose (Oenothera biennensis) from a field experiment. Eur. Soc. Evolutionary Biol. 22: 1295-1307.

Ibrahim, E.A. 2012. Variability, heritability, and genetic advance in Egyptian sweet melon (Cucumis melo var. aegyptiacus L.) under water stress condition. Intl. J.
Plant Breeding and Genetics. 6: 238244.

Kaufman, L., P.J. Rousseeuw. 1990. Finding Groups in Data: An Introduction to Cluster Analysis. Toronto $(\mathrm{CN})$ : John Wiley \& Sons Inc.

Khumaero, W., D. Efendi, W.B. Suwarno, Sobir. 2014. Evaluasi karakteristik hortikultura empat genotipe melon (Cucumis melo L.) Pusat Kajian Hortikultura Tropika IPB. J. Hort. Indonesia. 5(1): 56-63.

Liu, L., F. Kakihara, M. Kato. 2004. Characterization of six varieties of Cucumis melo L. based on morphological and physiological characters, including shelf-life of fruit. Euphytica. 135: 305-313.

Malik, A.A., V.K. Vashisht, K. Singh, A. Sharman, D.K. Singh, H. Singh, A.J. Monfore, J.D. McCreight, N.P.S. Dhillon. 2014. Diversity among melon (Cucumis melo L.) landraces from the Indo-Gangetic plains of India and their genetic relationship with USA melon cultivars. Genet Resour Crop Evol. DOI 10.1007/s10722-014-0101-x.

Manohar, S.H., H.N. Murthy. 2012. Estimation of phenotypic divergence in a collection of Cucumis melo, including shelf-life of fruit. Scientia Horticulturae 148: 74-82.

Ning, X., L. Xiong, X. Wang, X. Gao, Z. Zhang, L. Zhong, G. Li. 2014. Genetic diversity among Chinese Hami melon and its relationship with melon germplasm of diverse origins revealed by microsatellite markers. Biochemical Systematics and Ecology. 57: 432-468.

Nuñez-Palenius, H.G., M. Gomez-Lim, N. Ochoa-Alejo, R. Grumet, G. Lester, D.J. Cantliffe. 2008. Melon fruits: genetic diversity, physiology, and biotechnology features. Biotechnology. 28: 13-55. doi: 10.1080/07388550801891111. 
Obando-Ulloa, J.M., I. Eduardo, A.J. Monforte, J.P. Fernández-Trujillo. 2009. Identification of QTL related to sugar and organic acid compsition in melon using near-isogenic lines. Scientica Horticulturae. 121: 425-433.

Oh, S.H., B.S. Lim, S.J. Hong, S.K. Lee. 2011. Aroma volatile changes of netted muskmelon (Cucumis melo L.) fruit during developmental stages. Hort. Environ. Biotechnol. 52(6): 590-595.

Paris, M.K., J.E. Zalapa, J.D. McCreight, J.E. Staub. 2008. Genetic dissection of fruit quality components in melon (Cucumis melo L.) using a RIL population derived from exotic $\mathrm{x}$ elite US Western Shipping germplasm. Mol. Breeding. 22(3): 405-419. DOI: $10.1007 / \mathrm{s} 11032-$ 008-9185-3.

Robinson, R.W., D.S. Decker-Walters. 1999. Cucurbits. New York (US): CAB International.

Shashikumar, K.T., M. Pitchaimuthu, R.D. Rawal. 2010. Generation mean analysis of resistance to downy mildew in adult muskmelon plants. Euphytica. 173: 121127. doi: 10.1007/s10681-010-0132-0.

Suketi, K., R. Poerwanto, S. Sujiprihati, Sobir, W.D. Widodo. 2010. Analisis kedekatan hubungan antar genotipe pepaya berdasarkan karakter morfologi dan buah. J. Agron. Indonesia. 38(2): 130137.

Syukur, M., S. Sujiprihati, R. Yunianti. 2012. Teknik Pemuliaan Tanaman. Jakarta (ID): Penebar Swadaya.

Szamosi, C., I. Solmaz, N. Sari, C. Bársony. 2010. Morphological evaluation and comparison of Hungarian and Turkish melon (Cucumis melo L.) germplasm. Scientia Horticulturae. 124: 170-182.

[USDA] United States Departement of Agriculture. 2007. Network for a healthy California, Melons.

Wang, Y.H., D.H. Wu, J.H. Huang, S.J. Tsao, K.K. Hwu, H.F. Lo. 2016. Mapping quantitative trait loci for fruit traits and powdery mildew resistance in melon (Cucumis melo L.). Bot. Stud. 57(1): 19. doi: 10.1186/s40529-016-0130-1.

Zalapa, J.E., J.E. Staub, J.D. McCreight. 2006. Generation means analysis of plant architectural traits and fruit yield in melon. Plant Breeding. 125: 482-487.

Zalapa, J.E., J.E. Staub, J.D. McCreight. 2008 Variance component analysis of plant architectural traits and fruit yield in melon. Euphytica. 162: 129-143. 